\title{
In vitro antimicrobial activity of Caesalpinia coriaria (Jacq.) Willd extracts on Streptococcus pyogenes and Candida albicans
}

\author{
Actividad antimicrobiana in vitro de extractos de \\ Caesalpinia coriaria (Jacq.) Willd sobre Streptococcus \\ pyogenes y Candida albicans
}

Leanis Pitre-Ruiz ${ }^{1}$, Deycis Galván-Ayala ${ }^{\circledR}$, Omar Castro-Uriana ${ }^{1}{ }^{\circledR}$, Kelly Johanna Ávila Mendez ${ }^{2 \mathbb{C}}$, Silvio Alejandro Lopez-Pazos ${ }^{2+} \mathbb{( \mathbb { C }}$

\begin{abstract}
Background: "Dividivi" Caesalpinia coriaria (Jacq.) Willd fruits are traditionally used by the Wayuú community in La Guajira (Colombia) to treat oral and skin cavity diseases caused by bacteria and fungi. Streptococcus pyogenes is a gram-positive cocci of group A (betahemolytic) that is the cause of pharyngeal disease, scarlet fever, cellulitis, erysipelas, or toxic shock-like syndrome. Alternatively, Candida albicans is a yeast-like fungus that is a normal flora of the digestive tract, vagina, or skin folds; it has been known to be the root cause of opportunistic diseases such as diaper rash, oral and esophagus thrush, or vulvovaginitis. Objective: This study evaluated the antimicrobial activity of methanolic and ethanolic extracts of C. coriaria (Jacq.) Willd dry fruits on S. pyogenes ATCC 12384 and C. albicans ATTC 14053. Method: C. coriaria extracts were obtained from the Soxhlet method using two solvents (methanol and ethanol 98\%) prepared from pulverized fruits. A phytochemical test and an antimicrobial activity assay were performed using the obtained extracts and tested using $S$. pyogenes ATCC 12384 and C. albicans ATTC 14053 strains. Results: A phytochemical profile was performed, examining the presence of bioactive metabolites (tannins, alkaloids, glycosides, saponins, and anthraquinones) from each extract. Antimicrobial susceptibility tests showed that the ethanolic extract inhibited S. pyogenes ATCC 12384, causing inhibition halos of 14.1 $\pm 0.1 \mathrm{~mm}$ and a Minimum Inhibitory Concentration (MIC) of $172 \mathrm{mg} / \mathrm{ml}$, and C. albicans test shows inhibition halos of $16.1 \pm 0.2 \mathrm{~mm}$ and MIC of $212 \mathrm{mg} / \mathrm{ml}$. Additionally, the methanolic extract inhibited S. pyogenes with inhibition halos of $15.2 \pm 0.2 \mathrm{~mm}$ and MIC of $152 \mathrm{mg} / \mathrm{ml}$; no inhibitory effect was observed on $C$. albicans. Conclusion: This study revealed that $C$. coriaria has an antimicrobial effect on the tested species opening the field of its possible use as a therapeutic agent.
\end{abstract}

JOURNAL VITAE

School of Pharmaceutical and Food Sciences

ISSN 0121-4004 | ISSNe 2145-2660

University of Antioquia Medellin, Colombia

Filliations

${ }^{1}$ Universidad de la Guajira, Facultad de Ciencias Básicas y Aplicadas, Grupo de Investigación Biotecnología, Km 5 Vía Maicao, Riohacha, La Guajira, Colombia.

${ }^{2}$ Universidad Antonio Nariño, Faculty of Sciences, Carrera 3 Este 47A-15, Bogotá D.C., Colombia.

*Corresponding Silvio Alejandro Lopez-Pazos alejandrolopezpazos@uan.edu.co

Received: 21 February 2020 Accepted: 17 June 2021 Published: 22 June 2021

Key words: Caesalpinia coriaria extract, antimicrobial activity, Minimum Inhibitory Concentration, Streptococcus pyogenes, Candida albicans 


\section{RESUMEN}

Introducción: Los frutos del "Dividivi" Caesalpinia coriaria (Jacq.) Willd son usados tradicionalmente por la comunidad indígena Wayuú en La Guajira (Colombia) para el tratamiento de enfermedades de la cavidad bucal y cutáneas ocasionadas por bacterias y hongos. Streptococcus pyogenes es un coco grampositivo del grupo A (beta-hemolítico) que es la causa de enfermedad faríngea, escarlatina, celulitis, erisipela o síndrome tipo shock tóxico. Candida albicans es un hongo levaduriforme que es flora normal del tracto digestivo, la vagina o los pliegues de la piel; se sabe que es la causa principal de enfermedades oportunistas como la dermatitis del pañal, aftas bucales y esofágicas, o vulvovaginitis. Objetivo: El objetivo de este estudio fue evaluar la actividad antimicrobiana de extractos metanólicos y etanólicos de frutos secos sobre microorganismos patógenos específicamente S. pyogenes ATCC 12384 y C. albicans ATTC 14053. Método: A partir de frutos polverizados de C. coriaria, usando el método Soxlet, se evaluaron dos solventes (metanol y etanol al 98\%), los cuales, fueron usados para estudiar su actividad antimicrobiana evaluando su efecto en cepas de S. pyogenes ATCC 12384 y C. albicans ATTC 14053. Resultados: Mediante un perfil fitoquímico se determinó la presencia de grupos de metabolitos secundarios con compuestos bioactivos (taninos, alcaloides, glucósidos, saponinas, y antraquinonas). Las pruebas de sensibilidad antimicrobiana mostraron que el extracto etanólico tuvo un efecto inhibidor sobre $S$. pyogenes ATCC 12384 con halos de inhibición de $14.1 \pm 0.1 \mathrm{~mm}$ y una concentración mínima inhibitoria (CMI) de $172 \mathrm{mg} / \mathrm{mL}$, y sobre C. albicans se presentaron halos de inhibición de $16.1 \pm 0.2 \mathrm{~mm}$ y CMl de $212 \mathrm{mg} / \mathrm{mL}$, mientras que el extracto metanólico tuvo un efecto inhibidor sobre S. pyogenes con halos de inhibición de $15.2 \pm 0.2 \mathrm{~mm}$ y CMI de $152 \mathrm{mg} / \mathrm{mL}$ no se observó efecto inhibidor sobre C. albicans. Conclusión: Este estudio demostró que $C$. coriaria tiene efecto antimicrobiano en las especies evaluadas, abriendo un campo de investigación en la evaluación de su uso como agente terapéutico.

Palabras clave: Extracto de Caesalpinia coriaria, Actividad antimicrobiana, Concentración Mínima Inhibitoria, Streptococcus pyogenes ATCC 12384, Candida albicans ATTC 14053

\section{INTRODUCTION}

Humankind has used plants as a medical resource for the traditional treatment of various diseases, attributing a wide variety of therapeutic properties against bacteria and fungi (1). The isolation and identification of biologically active compounds and molecules have led to discovering new compounds, helping improve medical therapies and applications in different industries (2). Different plant materials have been selected based on their common interactions between plants and the environment, considering that secondary metabolites benefit different human applications (3). Plants are an extraordinary source of compounds with biological activity, which permits us to take advantage of them to treat various diseases (4). An example of this plant richness is the Caesalpinia genus with more than 500 species, with different classes of chemical compounds isolated, such as flavonoids, diterpenes, and steroids (5). Reports indicate that several species of this genus exhibit a wide range of pharmacological properties, including antiulcer, anticancer, antidiabetic, anti-inflammatory, antimicrobial, and antirheumatic activities that could have potential in ethnomedicinal practices $(6,7,8)$. Additionally, it is important to highlight that the richness of the products derived from Caesalpinia species are not only associated with pharmacological use but also agricultural industries (9), animal production (10), and environmental applications for the oil industry (11).
Group A beta-hemolytic Streptococcus pyogenes produce scarlet fever and strep throat. S. pyogenes are gram-positive cocci, which are non-motile round shape bacteria. This kind of microorganism synthesizes a toxin that causes a rash and a disease named streptococcal toxic shock-like syndrome. There is an overestimation of the bacterial source in throat infections, severe bronchitis, and S. pyogenes resistance to beta-lactam antibiotics. The fungus that most often causes cutaneous candidiasis is Candida albicans. C. albicans is a yeast-like microorganism that has been known to be the root cause of many recurrent and chronic diseases when they get out of equilibrium in the human organism, particularly in the vaginal tract, even though it can disturb the nail beds, mouth, and bloodstream $(12,13)$.

Due to inadequate consumption of antibiotics, an effect known as multiple drug resistance (MDR) is being generated in human medical services, which is a serious threat to public health; thus, antimicrobial compounds for the pharmaceutical industry are an important research issue $(2,14)$. Furthermore, the emergence of MDR among pathogenic microorganisms has limited the effectiveness of antibiotics, and this trend is a concern to agencies such as the World Health Organization. Faced with this problem, a search for bioactive compounds with antibiotic properties could be an alternative to MDR. In Colombia, specifically in the municipality of La Guajira, there is a wide probability of finding antimicrobial substances because of the presence of species of the genus Caesalpinia (15). Further, 
the Wayúu community that occupies this area uses fruit extracts of C. coriaria (Jacq.) Willd against different skin and mucous illnesses. Moreover, considering the MDR, it is necessary to search for new substances from unresearched $C$. coriaria with probably appealing performances, at least partially, on MDR pathogens including bacteria or fungi. Therefore, this study evaluated the antimicrobial activity of methanolic and ethanolic extracts of C. coriaria (Jacq.) Willd dry fruits on strains of $S$. pyogenes and C. albicans.

\section{MATERIALS AND METHODS}

\section{Extraction and preparation of plant extract.}

The C. coriaria material was collected in the Toroqui community (which belongs to Wayuu community) in the rural area of the municipality of Riohacha,

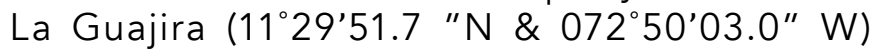
approximately $142.91 \mathrm{~m}^{2}$, the area is classified as tropical dry forest (16). The plant sample consisted of $500 \mathrm{~g}$ of ripe fruits of $C$. coriaria, applying a standard technique (17). First, the fruits were dried in a shadow and crushed to pulverize. The subsequent powder was stored in amber glass flasks at an average temperature of $25^{\circ} \mathrm{C}$ until processing. Then, $50 \mathrm{~g}$ of the pulverized material was taken to obtain the extract, and two extraction processes were realized as follows: (1) absolute methanol, (2) ethanol 98\%, applying in all cases the Soxhlet technique (for $2 \mathrm{~h}$ and $48 \mathrm{~h}$, using $200 \mathrm{~mL}$ of each solvent). Once the solvent had evaporated, a dry extract was obtained and stored aseptically under refrigeration at $4^{\circ} \mathrm{C}$ in hermetic bottles.

\section{Phytochemical tests.}

The plant extracts were subjected to screening to establish the presence of secondary metabolites through color tests as follows:

Shinoda's test for flavonoids: In a test tube, $3 \mathrm{~mL}$ of $10 \%$ extract, one fragment of magnesium tape was placed, and $1 \mathrm{~mL}$ of concentrated $\mathrm{HCl}$ was added. After 5 minutes of reaction, $1 \mathrm{~mL}$ of amyl alcohol was added. A yellow, orange, brown coloration indicates flavonoids.

Braemer's test for tannins: $0.3 \mathrm{~g}$ of dry extract was dissolved in $3-\mathrm{mL}$ methanol, and $2 \mathrm{~mL}$ of $10 \%$ alcoholic ferric chloride solution was added. The test was considered positive for tannins when the sample took on a bluish-black or green.
Test for alkaloids: In two test tubes, 1-mL extract and 1-mL HCL were added to each one. Meyer's reagent was added to the first tube and Wagner's reagent to the second, the formation of a cream precipitate was scored positive for Mayer's test, and the appearance of a brown precipitate for Wagner's test for the presence of alkaloids.

Test for Glycosides: $0.1 \mathrm{~g}$ of dry extract was dissolved in 2-mL pyridine, then 2-mL sodium nitroprusside solution was added after it was made alkaline with $5 \%$ sodium hydroxide solution. The sample, which turns pink to red indicates glycosides.

Test Afrosymetrical: With $0.4 \mathrm{~g}$ of the dry alcoholic extract in a test tube, $5 \mathrm{~mL}$ of distilled water was added. In a water bath, the solution was heated for 2 minutes and vigorously shaken. The test was considered positive for saponins when the foam persisted for 5 minutes or more (18).

Borntrager's Test: To $10-\mathrm{mL}$ benzene, $0.2 \mathrm{~g}$ of the alcoholic extract was added, which was stirred and filtered by gravity. $5 \mathrm{~mL}$ of $10 \%$ ammonium solution was added to this filtrate, and it was carefully stirred. The appearance of a pink, red, or violet in the ammoniacal (lower) phase was taken as the presence of free anthraquinones, according to Opinde and collaborators (19).

\section{Antimicrobial activity.}

S. pyogenes ATCC 12384 and C. albicans ATTC 14053 were obtained from the Microbiology Laboratory of the Universidad Popular del Cesar (Valledupar, Colombia). The antimicrobial activity of the extracts was performed applying the implemented Kirby-Bauer method (17). Disks impregnated $(6 \mathrm{~mm})$ with plant extract were placed with the following concentrations: 2,100, 1,050, 525 , and $262.5 \mathrm{mg} / \mathrm{mL}$ as a qualitative test, using a negative control (distilled water) and positive control (ampicillin $500 \mathrm{mg} / 10 \mathrm{~mL}$ for S. pyogenes and fluconazole $150 \mathrm{mg} / \mathrm{mL}$ for C. albicans), three replicates of each treatment were performed. They were incubated at $37^{\circ} \mathrm{C}$ for $24 \mathrm{~h}$ for $\mathrm{S}$. pyogenes ATCC 12384 and $48 \mathrm{~h}$ for C. albicans ATTC 14053. After the incubation time, the presence of inhibition halos around the impregnated discs was determined. The diameter of each halo was measured in millimeters ( $\mathrm{mm})(20)$, and the calculation of the percentage of the inhibitory effect relative to the positive control, which was proceeded by applying the following equation (21): 


\section{Equation 1:}

inhibitory effect $=\frac{\text { half inhibition halo dimeter }}{\text { Positive control inhibition halo diameter }} \times 100$

The presence or absence of an inhibition zone was used as a criterion to select the extract that best inhibited the growth of the pathogenic microorganisms understudied. Then, the disk diffusion test was performed, and Minimum Inhibitory Concentration (MIC) was determined on Mueller Hinton agar (S. pyogenes ATCC 12384) and $\mathrm{BHI}$ agar (C. albicans ATTC 14053) according to The Clinical and Laboratory Standards Institute (CLSI) using four filters Whatman paper discs $(6 \mathrm{~mm}$ diameter) impregnated with different concentrations of the extract $(262.5-152 \mathrm{mg} / \mathrm{mL})$ in the same incubation conditions. Therefore, we can figure out our data only with different diameters of inhibition. Finally, the collected data were analyzed using the ANOVA test (R software v.4.0.2.).

\section{RESULTS}

The principal aim of this study was to evaluate the antimicrobial effect of two extract types obtained from dry fruits of $C$. coriaria. First, the soxhlet method was conducted, getting different efficiencies between the methanol and ethanol extracts. Specifically, with methanol extract, a greater amount of dry extract was produced; the maximum value obtained was $14 \mathrm{~g}$, and with ethanolic extract, a maximum value of $8.5 \mathrm{~g}$ was obtained; in this way, the methanol presented higher yield rates. Additionally, a different secondary metabolite was identified from each extract (Tab. 1). Finally, the level of the obtained metabolite from each extract was evaluated visually according to the expected color for each phytochemical test.

Table 1. Type of secondary metabolite identified from Soxhlet technique using $200 \mathrm{~mL}$ of methanol and ethanol as solvent.

\begin{tabular}{lcc}
\hline \multirow{2}{*}{ Metabolites } & \multicolumn{2}{c}{ Extract } \\
\cline { 2 - 3 } & Methanol & Ethanol \\
\hline Flavonoids & + & + \\
Tannins & ++ & + \\
Alkaloids & +++ & ++ \\
Glycosides & ++ & + \\
Saponins & + & ++ \\
Anthraquinones & +++ & ++ \\
\hline
\end{tabular}

The current study supports previous findings in the literature that antimicrobial activities directly relate to increasing the concentration of the extracts. Significant antimicrobial effects of each $C$. coriaria extract on test microorganisms are given in Figures 1 and 2.

The ethanolic and methanolic extracts of $C$. coriaria showed antimicrobial activity on $S$. pyogenes ATCC 12384; the highest antimicrobial activity was recorded at 2,100 $\mathrm{mg} / \mathrm{mL}$ (Fig. 2, $\mathrm{p}<0,05$ ), and representing the highest inhibition percentage (29.6 for methanolic extract and 28.4 for ethanolic extract). A two-way ANOVA was performed for those samples. The main differences were found for the concentration variable, suggesting that the two evaluated extracts had no differential antimicrobial effect.

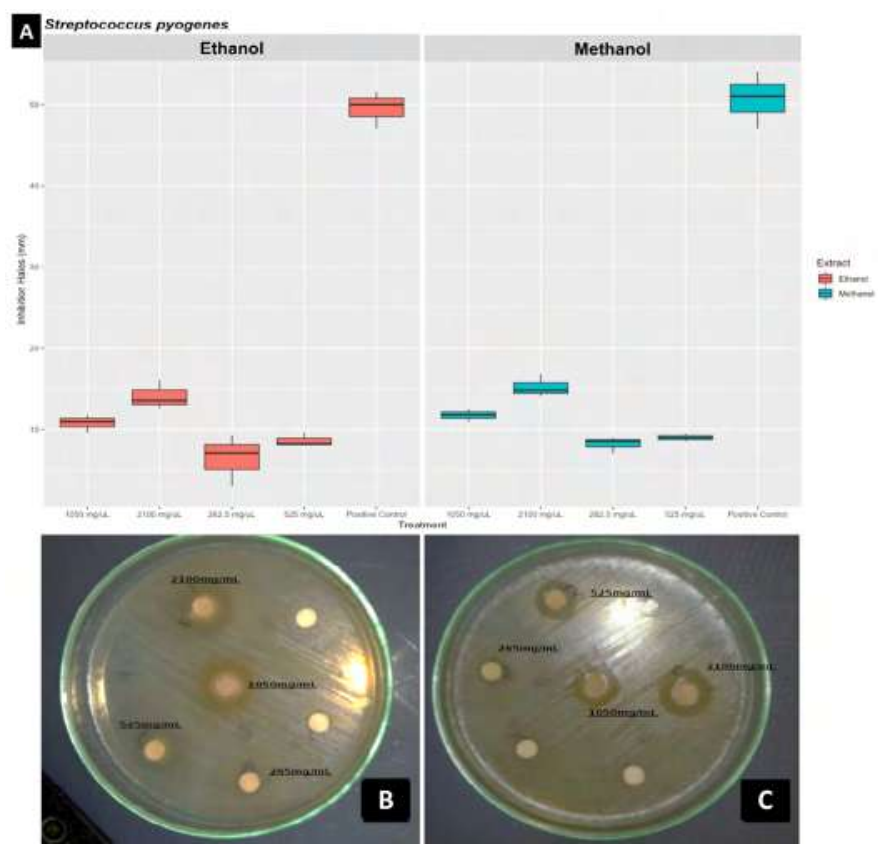

Figure 1. Antimicrobial evaluation of the methanolic and ethanolic extracts against S. pyogenes ATCC 12384. A: Boxplot of each extract and concentration. B and C Antibiogram, B: ethanol, $\mathrm{C}$ : methanol, disc without concentration mark were negative control (water).

Regarding the inhibitory effect on the strains of $C$. albicans ATTC 14053, only the ethanolic extract of C. coriaria showed antimicrobial activity, the highest response was obtained at a concentration of 2,100 $\mathrm{mg} / \mathrm{mL}$ (Fig. 2), and its inhibition percentage was 50.7 . 


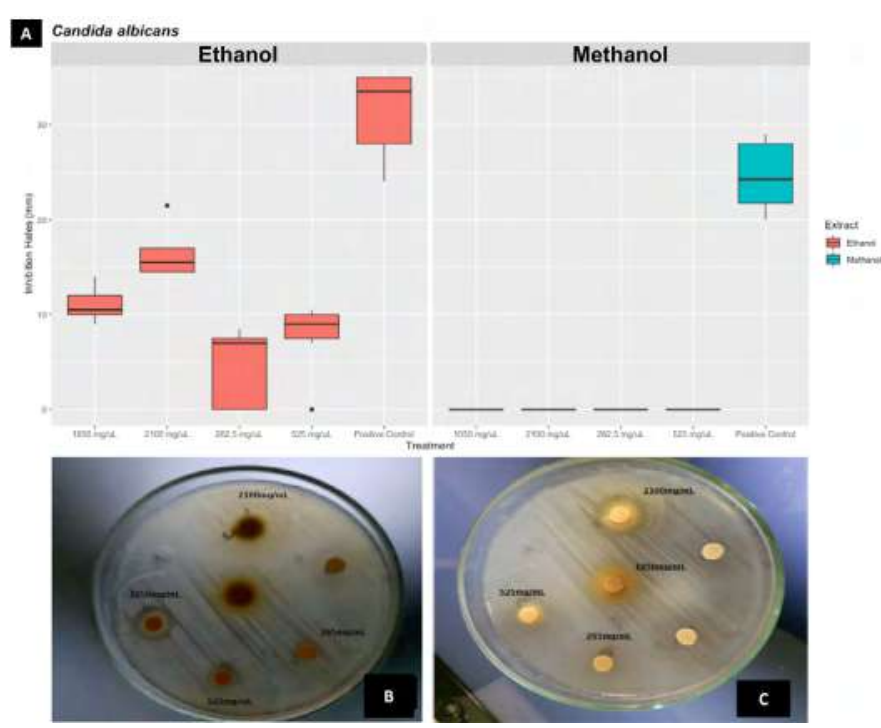

Figure 2. Antimicrobial evaluation of the extracts against $C$. albicans ATTC 14053. A. Boxplot for inhibition hales for different concentrations. B and C Antibiogram B: ethanolic extract and C: Methanolic extract, disc without concentration mark were negative control (water).

Finally, the C. coriaria extracts showed MIC against S. pyogenes ATCC 12384 at a concentration of $172 \mathrm{mg} / \mathrm{mL}$; concerning the results of the growth of C. albicans ATTC 14053 against the different concentrations of ethanolic extract of $C$. coriaria, it was established that the MIC was $212 \mathrm{mg} / \mathrm{mL}$.

\section{DISCUSSION}

The ethnobotany and ethnopharmacology disciplines define "medicinal plant" as those used in traditional medicine containing beneficial elements in the cure of diseases in humans and / or animals (2). This work evaluated the antimicrobial activity of methanolic and ethanolic extracts of C. coriaria (Jacq.) Willd dry fruits on S. pyogenes ATCC 12384 and C. albicans ATTC 14053. Therefore, the extraction efficiency of the fruit extract was first evaluated with the Soxhlet method. The results showed a highly efficient process, in which the extraction performed using methanol produced a more significant amount of dry extract; for this reason, it was considered the solvent with the highest yield compared to ethanol, which presented a lower efficiency.

Among the solvents most used today for extracting natural substances of biotechnological interest are aliphatic alcohols (methanol and ethanol) (22), these organic solvents are efficient, and their use is simple due to their low toxicity for humans, also, considering it safe and efficient extraction procedure (23). Furthermore, the concentration of solvents and their mass/volume ratio significatively affect the extraction of metabolites due to their excellent capacity to extract both lipid and watersoluble substances, which produce different yields and extract substances such as alkaloids, flavonoids, glycosides, and terpenes, among others (24). Finally, it is also important to highlight that extraction efficiency does not directly correlate with the inhibitory activity in the bacterial and yeast species evaluated in this study.

Regarding C. coriaria, this species is distributed in the Colombian Caribbean region, mainly in Atlántico, Bolívar, Cesar, La Guajira, Magdalena, and Sucre. This species is known to have abundant tannins, hence its many uses, such as dye leather. Rural communities from La Guajira prepare water and rinses to relieve tonsillitis, both from cooked fruits and infused leaves used to treat diarrhea (25, 26). This diversity of uses has also been reported in other countries, such as Mexico (27). The Caesalpinia genus with more than 500 species emerges as an alternative for investigating pharmacological activity, where different chemical compounds such as flavonoids, diterpenes, and steroids have been isolated $(5,25)$.

In this study, employing a phytochemical analysis, it was possible to determine glycosides, steroids, phenolic alkaloids, tannins, saponins, quinones, flavonoids, anthraquinones; however, some highlighted substances, such as coumarins, were not found in methanolic extracts. These results are similar to those reported by Mohana (29) and Anandhi et al. (30), who also reported tannins, quinones, carbohydrates, saponins, flavonoids, glycosides, cardiac glycosides, terpenoids, phenols, coumarins, proteins, steroids, and anthraquinones. However, they could not determine the presence of alkaloids and triterpenes; these differences were possibly due to intrinsic and extrinsic factors such as soil type, origin, environmental temperature, cultivation method, harvest, or extraction.

For the Caesalpinia genus, it has been reported that methanol extracts have a greater inhibitory effect in different microorganisms $(17,31)$; for example, high inhibitory activity is reported with methanolic extract using $C$. nepalensis (32). In other studies, it was possible to verify the antimicrobial activity of $C$. ferrea Martius on S. mutans, S. salivarius, S. oralis, and Lactobacillus, finding high effectiveness in MIC $(25,40,66$, and $100 \mu \mathrm{g} / \mathrm{mL})$ (30). Also, in ethanolbased extracts of $C$. mimosoides, they presented a $\mathrm{MIC}<1 \mathrm{mg} / \mathrm{mL}$ against bacterial and fungal strains $(34,35)$. 
Soares et al. (36) reported the antimicrobial activity of $C$. ferrea extracts against the most common oral pathogenic bacteria and fungi such as C. albicans, S. mutans, S. salivarius, S. oralis, and L. casei, showing to be more effective against $C$. albicans, by generating inhibition hales of $15 \mathrm{~mm}$ in diameter, these results are similar to those obtained in this work.

Sharma et al. (38) demonstrated that the antimicrobial activity of $C$. decapetala extracts against fungal strains (Aspergillus fumigatus and C. albicans), Gram-positive bacteria (Staphylococcus aureus and S. pyogenes), and Gram-negative bacteria (Escherichia coli and Pseudomonas aeruginosa) using the method dilution of the agar wells. The antibacterial effect presented by this plant species was attributed to phytoconstituents such as alkaloids, glycosides, phenols, phytosterols, saponins, and flavonoids, similar compounds found in this study.

Research by Glauber et al. (38), using other plant species, demonstrated antimicrobial activity of $C$. ferrea extracts against C. albicans, S. mutans, S. salivarius, S. oralis, and L. casei. They found inhibitory halos of $21 \mathrm{~mm}, 19.5 \mathrm{~mm}, 18.5 \mathrm{~mm}, 12 \mathrm{~mm}, 10 \mathrm{~mm}$, $11 \mathrm{~mm}, 13 \mathrm{~mm}$ through the disk diffusion method, which can be compared with the results obtained in our work with its intermediate effectiveness (see Figures. 1 and 2).

Finally, this great variability of results from different investigations suggests that the inhibitory effects of secondary metabolites depend on plant species, plant tissue, and extraction method. Therefore, more studies must establish precisely the maximum efficiency and inhibitory effects for specific species of bacteria and fungi and establish a baseline with data on species, plant tissue, and extraction method for performance and specific pharmacological research.

\section{CONCLUSION}

The plant species studied in this research was shown to have significant activity against selected microorganisms. We could confirm various phytochemicals in the extracts, highlighting the antibacterial and antifungal activity of extract of C. coriaria. It was concluded that the ethanolic extract of $C$. coriaria had the highest antibacterial activity against $S$. pyogenes and $C$. albicans. The phytochemical analysis showed that the extracts contain different molecules, assuming that dry fruits of $C$. coriaria contain bioactive compounds of potential therapeutic and prophylactic importance, and therefore it is a promising organism for research.

\section{CONFLICTS OF INTEREST}

The authors declare no conflict of interest in the present research.

\section{AUTHORS' CONTRIBUTIONS}

All authors participated equally in the development and writing of this article.

\section{FUNDING}

This work was funded by Centro de Investigaciones de Universidad de La Guajira (code CSI-2020-006) and the International Atomic Energy Agency - IAEA (code IAEA RLA5078).

\section{ACKNOWLEDGEMENTS}

The authors thank Sistema Integral de Laboratorios de la Universidad de La Guajira-SILAB for their contributions to both technical support and the research project.

\section{REFERENCES}

1. Sen T, Samanta SK. Medicinal plants, human health and biodiversity: a broad review. Advances in biochemical engineering/biotechnology. 2015; 147: 59-110. https://doi. org/10.1007/10_2014_273

2. Anand U, Jacobo-Herrera N, Altemimi A, Lakhssassi N. A Comprehensive Review on Medicinal Plants as Antimicrobial Therapeutics: Potential Avenues of Biocompatible Drug Discovery. Metabolites. 2019; 9(11): 258. https://doi.org/10.3390/ metabo9110258

3. AlSheikh HMA, Sultan I, Kumar V, Rather IA, Al-Sheikh H, Tasleem Jan A, Haq QMR. Plant-Based Phytochemicals as Possible Alternative to Antibiotics in Combating Bacterial Drug Resistance. Antibiotics (Basel, Switzerland). 2020; 9(8): 480. https://doi.org/10.3390/antibiotics9080480

4. Gupta C, Prakash D. Phytonutrients as therapeutic agents. Journal of complementary \& integrative medicine. 2014; 11(3): 151-169. https://doi.org/10.1515/jcim-2013-0021

5. Zanin JL, de Carvalho BA, Martineli PS, dos Santos MH, Lago JH, Sartorelli P, Viegas C Jr, Soares MG. The genus Caesalpinia L. (Caesalpiniaceae): phytochemical and pharmacological characteristics. Molecules (Basel, Switzerland). 2012; 17(7):78877902. https://doi.org/10.3390/molecules17077887

6. Arulmozhi P, Vijayakumar S, Kumar T. Phytochemical analysis and antimicrobial activity of some medicinal plants against selected pathogenic microorganisms. Microbial pathogenesis. 2018; 123 : 219-226. https://doi.org/10.1016/j.micpath.2018.07.009

7. Pájaro González Y, Méndez Cuadro D, Fernández Daza E et al. Inhibitory activity of the protein carbonylation and hepatoprotective effect of the ethanol-soluble extract of 
Caesalpinia coriaria Jacq. Orient Pharm Exp Med, 2016; 16: 225-232. https://doi.org/10.1007/s13596-016-0228-8

8. Sánchez-Carranza JN, Alvarez L, Marquina-Bahena S, Salas-Vidal E, Cuevas V, Jiménez EW, Veloz G RA, Carraz M, González-Maya L. Phenolic Compounds Isolated from Caesalpinia coriaria Induce S and G2/M Phase Cell Cycle Arrest Differentially and Trigger Cell Death by Interfering with Microtubule Dynamics in Cancer Cell Lines. Molecules (Basel, Switzerland),. 2017; 22(4): 666. https:// doi.org/10.3390/molecules22040666

9. Manuel-Pablo A, Elghandour MMY, Olivares-Pérez J, et al. Productive performance, rumen fermentation and carcass yield of goats supplemented with cascalote fruit (Caesalpinia coriaria J. Wild.). Agroforest Syst. 2020; 94: 1381-1391. https://doi. org/10.1007/s10457-018-0312-9

10. García-Hernández C, Rojo-Rubio R, Olmedo-Juárez A, Zamilpa A, Mendoza de Gives P, Antonio-Romo IA, Aguilar-Marcelino L, Arece-García J, Tapia-Maruri D, González-Cortazar M. Galloyl derivatives from Caesalpinia coriaria exhibit in vitro ovicidal activity against cattle gastrointestinal parasitic nematodes. Experimental parasitology. 2019; 200, 16-23. https://doi. org/10.1016/j.exppara.2019.03.012

11. Gallego MG, Rodríguez T, Rodríguez I, Almajano MP. Analytical Characterization of Polyphenols from Tara and Caesalpinia decapetala as Stabilizers of O/W Emulsions. Journal of food science. 2016; 81(11): C2676-C2685. https://doi.org/10.1111/17503841.13502

12. Walker MJ, Barnett TC, McArthur JD, Cole JN, Gillen CM, Henningham A, Sriprakash KS, Sanderson-Smith ML, Nizet V. Disease manifestations and pathogenic mechanisms of Group A Streptococcus. Clinical microbiology reviews. 2014; 27(2) 264-301. https://doi.org/10.1128/CMR.00101-13

13. Mayer FL, Wilson D, Hube B. Candida albicans pathogenicity mechanisms. Virulence. 2013; 4(2): 119-128. https://doi. org/10.4161/viru.22913

14. Kiraz N, Oz Y. Species distribution and in vitro antifungal susceptibility of clinical Candida isolates from a university hospital in Turkey over a 5-year period. Medical mycology. 2011; 49(2): 126-131. https://doi.org/10.3109/13693786.2010.503195

15. Rosado JR, Moreno MI. Farmacopea guajira: el uso de las plantas medicinales xerofíticas por la etnia wayuu. Revista CENIC. Ciencias Biológicas. 2010; 41:1-10.

16. Lennon RP, Lopez K, Socha J, Montealegre F, Chandler JW, Sweet NN, Hawley LA, Smith DK, Sanchack KE. Health Characteristics of the Wayuu Indigenous People. Military medicine. 2019; 184(7-8): e230-e235. https://doi.org/10.1093/milmed/usz021

17. De Jesús-Martínez $X$, Olmedo-Juárez A, Olivares-Pérez J, Zamilpa A, Mendoza de Gives P, López-Arellano ME, Rojas-Hernández S, Villa-Mancera A, Camacho-Díaz LM, Cipriano-Salazar M. In Vitro Anthelmintic Activity of Methanolic Extract from Caesalpinia coriaria J. Willd Fruits against Haemonchus contortus Eggs and Infective Larvae. BioMed research international. 2018, 7375693. https://doi.org/10.1155/2018/7375693

18. Valencia, E. F., Mac Donald, D., Cuyos, M., \& Dueñas, R. Extracción, identificación y evaluación de saponinas en agaricus bisporus. 2017, 5: https://doi.org/10.31381/biotempo.v5i0.889

19. Opinde, H. R., Nyamache, A. K., \& Gatheri, G. W. Antimicrobial activity, qualitative phytochemical composition of crude extracts from medicinal plants against selected enteric bacterial pathogens, Candida albicans. 2018. Bioteknologi Biotechnological Studies, 15(1), 1-12. https://doi.org/10.13057/ biotek/c150101

20. Torres Chati, J. Evaluación de la actividad antimicrobiana de extractos de Luma chequen (Molina) A. Gray" Arrayán" frente a patógenos aislados de hemocultivos del Hospital Nacional
Guillermo Almenara Irigoyen, 2014. Lima-Perú. Available from: https://cybertesis.unmsm.edu.pe/handle/20.500.12672/3605 Access: march 25th

21. Cruz-Carrillo, A., Rodríguez, N., \& Rodríguez, C. E. In vitro evaluation of the antibacterial effect of Bidens pilosa, Lantana camara, Schinus molle and Silybum marianum. Revista UDCA Actualidad \& Divulgación Científica. 2010. 13(2): 117-124.

22. Orozco Hayek Marcela. Eleccion de las condiciones más adecuadas para la obtencion de extractos de plantas superiores con actividad sobre una cepa de Staphylococcus aureus resistente.tesis maestria. 2004. Universidad Autonoma de Nuevo Leon. Facultad de medicina. Access on: http://eprints.uanl. $\mathrm{m} \times / 6668 / 1 / 1080123958$.PDF

23. Xavier, L.; Freire, M.S.; Vidal-Tato, I.; González-Álvarez, J. Application of aqueous two phase systems based on polyethylene glycol and sodium citrate for the recovery of phenolic compounds from Eucalyptus wood. Maderas. Ciencia y Tecnología 2015. 17(2):345-354. http://dx.doi.org/10.4067/ S0718-221X2015005000032

24. Soto-García, Marcela, \& Rosales-Castro, Martha. Efecto del solvente y de la relación masa/solvente, sobre la extracción de compuestos fenólicos y la capacidad antioxidante de extractos de corteza de Pinus durangensis y Quercus sideroxyla. Maderas. Ciencia y tecnología. 2016. 18(4): 701-714 https://dx.doi. org/10.4067/S0718-221X2016005000061

25. López C. R., Sarmiento C., Espitia L., Barrero A.M., Consuegra C., Gallego C., B. 2016. Divididi: Ichi Caesalpinia coriaria. En: López C. R., Sarmiento C., Espitia L., Barrero A.M., Consuegra C., Gallego C., B. 2016. 100 plantas del Caribe colombiano. Usar para conservar: aprendiendo de los habitantes del bosque seco. Fondo Patrimonio Natural, Bogotá D.C. Colombia. 75-76

26. Gina M. Rodríguez M., Karina Banda-R., Sandra Paola Reyes B. y Ana Cristina Estupiñán González. Lista comentada de las plantas vasculares de bosques secos prioritarios para la conservación en los departamentos de Atlántico y Bolívar (Caribe colombiano). Biota Colombiana, Vol 13 No 2 Julio-Diciemnbre, Especial Bosque Seco en Colombia.

27. Mora-Santacruz, Antonio., Roman-Mirando, Maria., GonzálezCuevas, Gerardo., Barrientos-Ramirez, Lucia. Chemical composition of cascalote Caesalpinia coriaria (Jacq.) Willd. and diversity of uses in the rural areas of dry tropics. Revista de Investigación y Desarrollo. 2018, 4(12): 24-28

28. Olmedo-Juárez A, Briones-Robles TI, Zaragoza-Bastida A Zamilpa A, Ojeda-Ramírez D, Mendoza de Gives P, Olivares-Pérez J, Rivero-Perez N. Antibacterial activity of compounds isolated from Caesalpinia coriaria (Jacq) Willd against important bacteria in public health. Microbial pathogenesis. 2019; 136: 103660. https://doi.org/10.1016/j.micpath.2019.103660

29. Mohana DC, Satish S, Raveesha KA. Antibacterial Evaluation of Some Plant Extracts Against Some Human Pathogenic Bacteria. Advances in biological research, 2008; 2(3-4), 49-55.

30. Anandhi D, Srinivasan PT, Revathi K, Revathy EK. Antibacterial Activity of Caesalpinia coriaria. Biosciences Biotechnology Research Asia. 2011; 8:759-764.

31. Rojas J.; Velasco J.; Buitrago A., Mender T.; Rojas J. (2016). Evaluación de la actividad antimicrobiana de plantas medicinales seleccionadas del Jardín Botánico del Orinoco, municipio Heres, Estado Bolívar. Rev Fac Farm. 2016; 58(1): 2-10.

32. Kumar P, Bhatt RP, Singh L, Sati OP, Khan A, Ahmad A. Antimicrobial activities of essential oil and methanol extract of Coriaria nepalensis. Natural product research. 2011; 25(11): 1074-1081. https://doi.org/10.1080/14786419.2010.529545

33. Sampaio FC, Pereira Mdo S, Dias CS, Costa VC, Conde NC, Buzalaf MA. In vitro antimicrobial activity of Caesalpinia ferrea Martius 
fruits against oral pathogens. Journal of ethnopharmacology. 2009: 124(2), 289-294. https://doi.org/10.1016/j.jep.2009.04.034

34. Thippeswamy S, Mohana DC, Manjunath K. (2012). Screening of in vitro antifungal activity of some indian medicinal plants against Candida albicans and Cryptococcus neoformans. International Journal of Current Research. 2012; 4(3): 37-42.

35. Bhat PB, Hegde S, Upadhya V, Hegde GR, Habbu PV, Mulgund GS. Evaluation of wound healing property of Caesalpinia mimosoides Lam. Journal of ethnopharmacology, 2016; 193: 712-724. https://doi.org/10.1016/j.jep.2016.10.009

36. Soares, M. R., Corrêa, R. O., Stroppa, P. H. F., Marques, F. C., Andrade, G. F., Corrêa, C. C., \& Raposo, N. R. Biosynthesis of silver nanoparticles using Caesalpinia ferrea (Tul.) Martius extract: physicochemical characterization, antifungal activity and cytotoxicity. 2018. PeerJ, 6, e4361. https://doi.org/10.7717/ peerj.4361

37. Sharma V, Lobo R, Singh G, Chanana V, Kalsi V ,Suttee A. Antimicrobial Evaluation of Caesalpinia decapetala, 2017. IJPPR, Volume 9 (12): 1421-1424. rch 2017; 9(12); 1421-1424. https://doi. org/10.25258/phyto.v9i11.11185

38. Glauber P. Oliveira; Tatiane P. Souza; Sheila K. Caetano; Kaliny S. Farias; Gisely N. Venancio; Maria F. C. L. Bandeira1; Nikeila C. O. Conde. Atividade antimicrobiana in vitro de extratos da casca do caule e da vagem de Libidibia ferrea $L$. frente a microrganismos da cavidade bucal Revista Fitos, Rio de Janeiro. 2013. Vol. 8(2): 73-160. 